\title{
Does the Implementation of the Management Function Have an Impact on Service Quality? A Study at the HSC Fitness Center
}

\author{
Ahmad Nasrulloh ${ }^{*}$, Sumaryanto, Sumarjo, Sigit Nugroho, Muhammad Sigit Antoni \\ Faculty of Sport Science, Yogyakarta State University, Yogyakarta 55281, Indonesia
}

Received April 8, 2021; Revised August 24, 2021; Accepted September 21, 2021

\section{Cite This Paper in the following Citation Styles}

(a): [1] Ahmad Nasrulloh, Sumaryanto, Sumarjo, Sigit Nugroho, Muhammad Sigit Antoni, "Does the Implementation of the Management Function Have an Impact on Service Quality? A Study at the HSC Fitness Ceasnter," International Journal of Human Movement and Sports Sciences, Vol. 9, No. 5, pp. 1019 - 1028, 2021. DOI: 10.13189/saj.2021.090524.

(b): Ahmad Nasrulloh, Sumaryanto, Sumarjo, Sigit Nugroho, Muhammad Sigit Antoni (2021). Does the Implementation of the Management Function Have an Impact on Service Quality? A Study at the HSC Fitness Center. International Journal of Human Movement and Sports Sciences, 9(5), 1019 - 1028. DOI: 10.13189/saj.2021.090524.

Copyright $\bigcirc 2021$ by authors, all rights reserved. Authors agree that this article remains permanently open access under the terms of the Creative Commons Attribution License 4.0 International License

\begin{abstract}
The management of a fitness center needs to apply good management functions in order to improve the quality of its service. HSC Fitness Center is one of the public services which are engaged in physical fitness. The purpose of this study was to determine the impact of the application of management functions on service quality at the HSC Fitness Center Yogyakarta. This research uses qualitative and quantitative approaches (mixed method) with data collection techniques through observation, interview, documentation and questionnaire methods. The data sources of this study consisted of directors, managers, front office staff, fitness instructors and members of the HSC Fitness Center. Data collection on the application of management functions is obtained from observations and interviews with data sources, while data on service quality is known by using an instrument in the form of a questionnaire. Based on the results of research and discussion, it can be concluded that the overall HSC Fitness Center Yogyakarta has implemented management functions in the form of planning, organizing, placing, directing, and controlling optimally. This implementation has a positive impact on service quality which includes several factors: reliability, tangibles, responsiveness, assurance, and empathy.
\end{abstract}

Keywords Management, Service, HSC Fitness Center

\section{Introduction}

Physical health and fitness are something that everyone desires in life. Various attempts are made by someone to get health and fitness. One way that is often done is by doing physical activity or exercising. To obtain physical health and fitness, exercise must be carried out in accordance with the exercise dose so that it can be measured, regular and programmed [1], [2]. The number of people who like to exercise is increasing, because now there are many sports venues that provide service facilities in an indoor facility, so that there are no obstacles such as sun heat or rain when exercising. Various sports facilities in the form of services that are currently developing and popular today. Those are tennis, football, basketball, and sports in the form of weight training in a fitness center.

One of the sports activities that are currently developing is sports activities in a fitness center. These days, exercising in a fitness center has become part of a lifestyle that is favored by various groups of people, both students, graduated students and parents. Various groups of people come to the fitness center with the purpose of improving their health and fitness by carrying out various sports programs including weight loss programs, body shaping programs, weight gain, muscle mass gain (body building), weight training program and strength program [3], [4], [5], [6].

The fitness center is one of the favorite places to 
exercise by the community because the fitness center has various tools and facilities designed in such a way that it can be used as a proper physical exercise. According to Suharjana, a fitness center is an indoor sports place that offers various fitness training programs with modern facilities and equipment for the purpose of achieving health, fitness, and achievement [7].

Everyday life of every human being is a management of himself or his family. This is done in some effort to meet the needs of the family and realize the goals he or she wants. Management is a process carried out by the organization to plan, organize, direct, and control all activities of the organization members and utilize various available resources to achieve organizational goals [8], [9]. Sports management is the implementation of planning, organizing, directing, motivating, and controlling processes in an organizational context which has the main objective of providing sports activities, products and services or physical fitness as an effort to develop and advance the company [10], [11], [12]. Another opinion was that management is a work activity that coordinates and supervises other people's work [13], [14].

The definition of management as a process in translation and how to define it given by experts is still vary. Some experts define management as a process. In the Encyclopedia of the Social Sciences, it is stated that management is a process with the implementation of a certain goal which is organized and supervised. Manullang according to the literature management has three definitions: 1) management as a process, 2) management as a collective people who do management, and 3) management as an art and as a science [15]. Based on those opinions of the experts above, it can be concluded that management is an activity of the leadership by using all the necessary resources to achieve organizational goals efficiently. Management is also defined as the process carried out by the organization to plan, organize, direct, control all activities of the members of the organization to achieve organizational goals.

At this time, fitness center entrepreneurs must manage their fitness clubs as well as possible. Fitness center management must apply good management functions in order to maintain the quality of its service. The management function is basically the main task that must be carried out by the leadership in every organization. The management function consists of four functions consist of planning, organizing, leading, and control [16], [17]. Planning is determining organizational goals and deciding the best way to achieve them. Organizing is the determination of steps or tasks to achieve organizational goals and organizing the right people and other resources to carry out predetermined plans. Leading is defined as a leadership. After establishing the planning and organizing the necessary resources, the third function of management is the leadership. Leadership (leading) is often referred to as directing. The management function is the process of planning, organizing, directing and controlling the efforts of members, organizations, and the use and control of human resources owned by the organization. The management function is a series of processes for planning, organizing, directing and controlling the efforts of the members, the organization, the use and control of human resources owned by the organization to achieve the goals of the organization [18], [19].

Service quality is an effort to fulfill customer needs and desires, as well as the accuracy of its delivery to balance customer expectations. "Quality is the level of excellence that is expected from control over that level of excellence to fulfill. A very important aspect in determining the quality associated with service to members is the quality of service. Excellent service is defined as an attitude or way of employees serving customers satisfactory [20], [21]. Broadly speaking, Nasution states that there are four main elements in the concept of quality, namely speed, accuracy, friendliness, and comfort. Service is said to be good if each employee has certain skills, including good and neat appearance, being friendly, showing morale and being always ready to serve customers, being able to communicate well, and having the ability to handle customer complaints [22].

The image of good service quality is not based on the point of view or perception of the service provider, but based on the point of view or perception of consumers. Based on some of the opinions above, it is concluded that service quality is a condition of the performance of an organization in providing services for customers with the aim of providing satisfaction to customers. There are five dimensions related to service quality: tangibles, reliability, responsiveness, assurance, and empathy [23], [24], [25].

The concept of service quality basically provides a concrete perception of the quality of a service. The concept of service quality is a comprehensive and permanent revolution in changing one's perspective in carrying out or working on any business related to a dynamic and continuous process in fulfilling hopes, wants and needs. This is in accordance with the Quality theory that the success of a service action is determined by quality, and quality is the highest appreciation of service action [26], [27].

That the concept of service quality is a perception of a quality revolution as a whole that is thought of and becomes an idea that must be formulated, so that its implementation can be evaluated, to become a dynamic process and to take place continuously in meeting customer satisfaction [28]. The theory of "goals" developed by Samuelson (2000) shows that goals are assumptions of satisfaction that are adjusted to the level of service quality [29].

The concept of service quality is basically a quality standard that must be understood in providing services which are closely related to marketing and service quality. This is in accordance with Yong and Loh that the quality 
of service must be adjusted to a proper standard, such as ISO (International Standardization Organization) standards so that a healthy condition is considered for its purpose or use, which conforms to specifications, freedom with all its shortcomings, forms customer satisfaction, and has high credibility and is pride [30].

Management is all activities to mobilize a group of people and move all existing facilities in an effort to cooperate with a group of people to achieve certain goals. In order for the management of a fitness center to run well, it must apply management functions. Good management processes must meet management function standards which include: (1) planning (2) organizing, (3) assigning employees, (4) directing, and (5) controlling. With the application of this management function, it is hoped that it will be able to have a positive impact on the quality of Fitness Center services. The observed service quality indicators include: reliability, tangibles, responsiveness, assurance, and empathy.

HSC Fitness Center is one of the fitness centers in Yogyakarta and is a part of a business that is engaged in services in the field of physical fitness. In providing services to customers, HSC Fitness Center is required to pay attention to and implement good management functions. In this study, the researcher intends to conduct a study on the application of management functions in the management of the HSC Fitness Center and determine the impact of the application of the management function on the quality of service at the HSC Fitness Center. The management functions observed are planning, organizing, employee placement, directing, and controlling. Service quality indicators that are studied in this study include: reliability, tangibles, responsiveness, assurance, and empathy. This research is important so that the HSC Fitness Center can find out the effect of the implementation of the management function on service quality. By knowing the effect of implementing the management function on service quality, other fitness centers can also pay attention to the implementation of management functions to improve their service quality.

\section{Materials and Methods}

The design in this study uses qualitative and quantitative approaches (mixed method). As a research method, mixed method focuses on collecting, analyzing and mixing qualitative and quantitative data carried out in one or a series of studies. The research was conducted at the Health and Sport Center (HSC) Fitness Center Yogyakarta, Jl. Colombo number 1 Yogyakarta. The data collection process was carried out between May and June 2020. The variables examined in this study included the application of management functions in the form of planning, organizing, placing, directing, and controlling effectively as well as the impact on service quality at the
HSC Fitness Center which includes: reliability, tangibles, responsiveness, assurance, and empathy [31].

The sampling technique was purposive sample. The research subjects were the managers of the HSC Fitness Center which included directors, managers, front office staff, fitness instructors and members of the HSC Fitness Center. This study applies a human instrument model with observation and interview guidelines as a research instrument to obtain data about management functions at the HSC Fitness Center. Interviews were conducted in an integrated manner with an outline of the interview guide covering aspects that will be known about the management function at the HSC Fitness Center. Observations are carried out transparently and strengthened by documentation in the form of field notes and photos. To obtain service quality, this study used an instrument in the form of a questionnaire. The questionnaire in this study was developed according to the analysis theory of the management function [8] and analysis of service quality [22]. The validity of the research instrument was determined by calculating the validity using Pearson's Product Moment formula, while the reliability of the instrument was determined using Cronbach's Alpha formula with the help of a statistical program. The data analysis technique in this study was carried out by two methods of analysis. Data regarding the management function is analyzed by means of qualitative data analysis, which consists of three components, namely data reduction, data presentation, and drawing conclusions and verification. Data regarding service quality were analyzed using descriptive analysis techniques by categorizing the data to determine the level of service quality. In this study, the data were categorized into five categories, namely very good, good, sufficient, insufficient and very lacking.

\section{Discussion}

\subsection{Result}

\subsubsection{Description of Interview Result Data}

The interview subjects in this study were 9 speakers who were directly involved with the Yogyakarta HSC Fitness Center. The speakers include general managers, secretaries, managers, instructor coordinators, instructors and front office staff. The interview focused on the management functions at HSC Fitness Center Yogyakarta which included 1) planning, consisting of global planning, strategic, and operational sub-indicators, 2) organizing, consisting of sub indicators observed in this research including the preparation of work organizations, determining sources human resources and responsibility supervision), 3) Planning, including sub indicators of human resource planning, employee withdrawal, employee orientation, training, appraisal, and 
remuneration), 4) Direction, including sub indicators leading, motivating and communicating, 5) controls, including aspects of personal controls, action controls and result controls .

Based on interviews about global planning, strategic planning and operational planning at the HSC Fitness Center, it is known that 9 informants stated that the HSC Fitness Center has global planning, strategic planning and operational planning. Institutionally, global planning is prepared based on the mechanism of the Faculty of Sport Sciences: Dean - manager - unit manager - then continued to human resources. The prepared global plan is used for managerial work guidelines, covering the overall managerial such as revenue targets, human resources, facilities and others. Strategic planning is used as a guideline for formulating work strategies to achieve predetermined targets, while operational planning becomes a guideline for carrying out operational work activities of the HSC Fitness Center.

Organizing is the process of preparing an organizational structure in accordance with the organizational goals of its resources and the environment that surrounds it. Based on interviews, the process of compiling the work organization of the Yogyakarta HSC Fitness Center was prepared by the authorized parties at the FIK and HSC Fitness Center and continued at the University level. The determination of human resources at the HSC Fitness Center is carried out based on the needs of the work unit, then the recruitment of the required human resources is carried out. The criteria for determining human resources at the HSC Fitness Center include education level, scientific fields, special professions (masseur/ instructor/ personal trainer), and work experience. Besides that, the main things that are also considered are attitude, personality and character. The HSC Fitness Center has also supervised the responsibilities carried out by the head of the HSC Fitness Center division and is evaluated every month through an internal meeting. The monitoring report was submitted to the leaders of HSC, Faculty of Sport Science and Yogyakarta State University. HSC Fitness Center has also done HR planning.

The HR planning aspect in the placement function at the HSC Fitness Center is tailored to the HR needs of the HSC Fitness Center. The withdrawal of employees at the HSC Fitness Center is carried out through a selection stage, but the priority is that employees are recruited from FIK UNY, who on average have interned at the HSC Fitness Center. Regarding employee orientation, most of the informants stated that there has already been an employee orientation at the Yogyakarta HSC Fitness Center. Work orientation is carried out in each work unit by introducing the work environment, explaining the vision and mission and job descriptions, as well as introducing problems that are often encountered in the field. Based on the results of interviews with informants about job training, the majority of informants stated that there had been employee training at the Yogyakarta HSC Fitness Center. Informants who state that there is no job training may not have been included in the training, but the job training program itself is a policy of the Yogyakarta HSC Fitness Center which is conducted every 3 to 6 months as needed. Job appraisals have been carried out at the HSC Fitness Center Yogyakarta. Basically, the assessment is done every day and evaluated once a month during the coordination meeting. Furthermore, there is a re-evaluation as a condition for continuing the work contract once a year. Some of the informants stated that there was no remuneration for employees at the HSC Fitness Center. This means that the aspect of providing remuneration has not been fulfilled by the Yogyakarta HSC Fitness Center.

Direction is the process of directing and influencing members of the organization individually or as a whole in carrying out various activities to achieve a goal or set of goals. Based on the results of interviews with informants, it is known that most have implemented a leadership pattern by adopting a democratic leadership pattern. In terms of motivation, the results of the interviews indicated that motivation was given at the HSC Fitness Center, which was given by the manager to employees as well as among the employees themselves. Effective communication patterns have also been implemented at the Yogyakarta HSC Fitness Center. Communication is carried out openly, which includes dialogue and discussion, being a good listener to others and always respecting other people's ideas, input, and opinions.

From the aspect of control based on the results of the interview, it is known that the HSC Fitness Center has implemented personal control, action control, and result control. These personal controls include being carried out by managers on employees by means of a personal approach, evaluating, giving advice, being reprimanded and given constructive sanctions. Action controls are carried out by controlling the work carried out by employees in accordance with the duties and duties of each employee, and result controls are carried out by evaluating work results regularly, respecting employee work results, discussing complaints and aspirations by increasing concern with employees. Result controls are generally carried out through daily and monthly meetings to evaluate performance, as well as annual meetings to evaluate year-end assessments.

\subsection{Data Observation}

Apart from being obtained from interviews, management function data is also complemented by observations. Observation data will complement the results of the interview. 
Table 1. Observation Results Regarding Management Functions of The HSC Fitness Center

\begin{tabular}{|c|c|c|c|c|}
\hline & \multirow{2}{*}{ Observation } & \multicolumn{2}{|c|}{ Qualification } & \multirow[t]{2}{*}{ Description } \\
\hline & & Yes & None & \\
\hline \multicolumn{5}{|c|}{ Planning } \\
\hline $\begin{array}{l}\mathrm{a} \\
\mathrm{b} \\
\mathrm{c}\end{array}$ & $\begin{array}{l}\text { Whether there is global planning or not } \\
\text { Whether there is strategic planning or not } \\
\text { Whether there is operational planning or not }\end{array}$ & $\begin{array}{l}\sqrt{ } \\
\sqrt{ } \\
\sqrt{ }\end{array}$ & & $\begin{array}{l}\text { Planning is carried out through meetings every } \\
\text { month, with a breakdown in each unit. }\end{array}$ \\
\hline \multicolumn{5}{|c|}{ Organizing } \\
\hline $\begin{array}{l}\mathrm{b} \\
\mathrm{c}\end{array}$ & $\begin{array}{l}\text { Whether there is a work organization arrangement or } \\
\text { not } \\
\text { Whether there is a determination of human resources } \\
\text { Whether there is oversight of certain responsibilities }\end{array}$ & $\begin{array}{l}\sqrt{ } \\
\sqrt{ }\end{array}$ & & $\begin{array}{l}\text { The organizational structure follows the management } \\
\text { unit of the HSC management }\end{array}$ \\
\hline \multicolumn{5}{|c|}{ Placement } \\
\hline $\begin{array}{l}\text { a } \\
b \\
c \\
d \\
\text { d } \\
\text { f }\end{array}$ & $\begin{array}{l}\text { HR planning } \\
\text { Employee withdrawal } \\
\text { Employee orientation } \\
\text { Employee training } \\
\text { Employee assessment } \\
\text { Providing remuneration for employees }\end{array}$ & $\begin{array}{l}\sqrt{ } \\
\sqrt{ } \\
\sqrt{ } \\
\sqrt{ } \\
\sqrt{ }\end{array}$ & $\sqrt{ }$ & $\begin{array}{l}\text { Conducted in each unit through the existing } \\
\text { considerations and conditions }\end{array}$ \\
\hline \multicolumn{5}{|c|}{ Leading } \\
\hline $\begin{array}{l}\mathrm{a} \\
\mathrm{b} \\
\mathrm{c}\end{array}$ & $\begin{array}{l}\text { Lead } \\
\text { Motivate } \\
\text { Communicate }\end{array}$ & $\begin{array}{l}\sqrt{ } \\
\sqrt{ } \\
\sqrt{ }\end{array}$ & & Each unit is directed by their respective management \\
\hline \multicolumn{5}{|c|}{ Controlling } \\
\hline $\begin{array}{l}\mathrm{a} \\
\mathrm{b} \\
\mathrm{c}\end{array}$ & $\begin{array}{l}\text { Personal controls } \\
\text { Action controls } \\
\text { Result controls }\end{array}$ & $\begin{array}{l}\sqrt{ } \\
\sqrt{ } \\
\sqrt{ }\end{array}$ & & Performed in each unit \\
\hline
\end{tabular}

Based on observations, it is known that management functions including planning, organizing, placing, directing and controlling have been carried out at the Yogyakarta HSC Fitness Center. The planning function has been carried out with the existence of global, strategic and operational planning. The organizing function has been carried out by the HSC Fitness Center Yogyakarta by arranging work organization, determining human resources and monitoring responsibilities. The organizational structure follows the management unit of the HSC management. All aspects of leadership and managerial have carried out the organizing function together. The placement function is carried out by the Yogyakarta HSC Fitness Center with the existence of HR planning, employee recruitment, employee training, employee appraisals and employee orientation. What has not been done is that there is no remuneration for employees. The placement function is carried out in each unit through consideration and adjusted to the conditions and needs of each unit. This supports positive organizational performance at the HSC Fitness Center [32], [33].

The function of directing has been carried out by the HSC Fitness Center Yogyakarta, indicated by the existence of leading, motivating and communicating in the management of the HSC Fitness Center. The directing function is performed in each unit. The control function has also been carried out by the HSC Fitness Center Yogyakarta, indicated by the presence of personal controls, action controls and result controls. Overall, the management function has been carried out by the HSC Fitness Center Yogyakarta and with this. It is hoped that it can support optimal service at the HSC Fitness Center.

\subsection{Description of Service Quality Data Analysis Results}

Service quality data for HSC Fitness Center Yogyakarta is divided into 5 factors, namely direct evidence, reliability, responsiveness, assurance and empathy [34], [35], [32], [36]. The data of each service quality factor of HSC Fitness Center Yogyakarta were analyzed descriptively with the following results.

\subsubsection{Service Quality Direct Evidence Factors}

Direct evidence service quality is observed based on indicators of physical evidence, equipment and means of communication at HSC Fitness Center Yogyakarta. The results of the research in the category of service quality at the HSC Fitness Center and the direct evidence factors are as follows: 
Table 2. Direct Evidence Data Categorization

\begin{tabular}{cccc}
\hline Interval Score & Frequency & $\begin{array}{c}\text { Percentage } \\
(\mathbf{\%})\end{array}$ & Category \\
\hline$x \geq 32,50$ & 26 & 52,0 & Very good \\
\hline $27,50 \leq$ to $<32,50$ & 20 & 40,0 & Good \\
\hline $22,50 \leq$ to $<27,50$ & 4 & 8,0 & Sufficient \\
\hline $17,50 \leq$ to $<22,50$ & 0 & 0,0 & Bad \\
\hline$x<17,50$ & 0 & 0,0 & Very bad \\
\hline Total & 50 & 100,0 & \\
\hline
\end{tabular}

Based on the table above, it is known that $52 \%$ of the respondents stated that direct evidence was in the very good category, while $40 \%$ of the respondents stated that direct evidence was in the good category. Respondents who stated that the direct evidence category is sufficient is $8 \%$. Generally, it can be concluded that the service quality of direct evidence is in the very good category.

\subsubsection{Service Quality Reliability Dimensions}

The service quality of the reliability factor is observed based on the indicators of timely service delivery and the suitability of services at HSC Fitness Center Yogyakarta. The categorization for the reliability factor is presented in the following table:

Table 3. Reliability Data Categorization

\begin{tabular}{cccc}
\hline Interval Score & Frequency & $\begin{array}{c}\text { Percentage } \\
\mathbf{( \% )}\end{array}$ & Category \\
\hline$x \geq 29,25$ & 19 & 38,0 & Very good \\
\hline $24,75 \leq$ to $<29,25$ & 25 & 50,0 & Good \\
\hline $20,25 \leq$ to $<24,75$ & 6 & 12,0 & Sufficient \\
\hline $15,75 \leq$ to $<20,25$ & 0 & 0,0 & Bad \\
\hline$x<15,75$ & 0 & 0,0 & Very bad \\
\hline Total & 50 & 100,0 & \\
\hline
\end{tabular}

Based on the table above, it is known that $50 \%$ of the respondents stated that the reliability was in the good category, by $38 \%$ of the respondents stated that the reliability was in the very good category. Respondents who stated that the reliability category was sufficient at $12 \%$. Generally, it can be concluded that the service quality reliability factor is in good category.

\subsubsection{Service Quality of the Responsiveness Dimension}

The service quality of the responsiveness factor is observed based on the response indicators and employee readiness, and the time available for service at the HSC Fitness Center Yogyakarta. The categorization for the responsiveness factor is presented in the following table:
Table 4. Responsiveness Data Categorization

\begin{tabular}{cccc}
\hline Interval Score & Frequency & $\begin{array}{c}\text { Percentage } \\
(\%)\end{array}$ & Category \\
\hline$x \geq 22,75$ & 28 & 56,0 & Very good \\
\hline $19,25 \leq$ to $<22,75$ & 21 & 42,0 & Good \\
\hline $15,75 \leq$ to $<19,25$ & 1 & 2,0 & Sufficient \\
\hline $12,25 \leq$ to $<15,75$ & 0 & 0,0 & Bad \\
\hline$x<12,25$ & 0 & 0,0 & Very bad \\
\hline Total & 50 & 100,0 & \\
\hline
\end{tabular}

Based on the table above, it is known that $56 \%$ of the respondents stated that responsiveness was in the very good category, while $42 \%$ of the respondents stated that responsiveness was in the good category. Respondents who stated that the responsiveness category was adequate by $2 \%$. Generally, it can be concluded that the service quality of the responsiveness factor is in the very good category.

\subsubsection{Quality of Service Dimensions of Guarantee}

Service quality assurance factor is observed based on security and safety assurance indicators, knowledge and capabilities of human resources at HSC Fitness Center Yogyakarta. The categorization for assurance factors is presented in the following table:

Table 5. Guarantee Data Categorization

\begin{tabular}{cccc}
\hline Interval Score & Frequency & $\begin{array}{c}\text { Percentage } \\
(\%)\end{array}$ & Category \\
\hline $\mathrm{x} \geq 22,75$ & 26 & 52,0 & Very good \\
\hline $19,25<$ to $<22,75$ & 23 & 46,0 & Good \\
\hline $15,75<$ to $<19,25$ & 1 & 2,0 & Sufficient \\
\hline $12,25<$ to $<15,75$ & 0 & 0,0 & Bad \\
\hline $\mathrm{x}<12,25$ & 0 & 0,0 & Very bad \\
\hline Total & 50 & 100,0 & \\
\hline
\end{tabular}

Based on the table above, it is known that $52 \%$ of the respondents stated that the guarantee was in the very good category, while $46 \%$ of the respondents stated that the guarantee was in the good category. Respondents who stated that the category guarantee was sufficient by $2 \%$. It can be concluded that the service quality assurance factor is in the very good category.

\subsubsection{Service Quality Dimensions of Empathy}

The service quality of the empathy factor is observed based on the indicators of empathy, namely the company's attention to members, understanding the needs of members and the ease of making relationships at the HSC Fitness Center Yogyakarta. The categorization for empathy factors is presented in the following table: 
Table 6. Empathy Data Categorization

\begin{tabular}{cccc}
\hline Interval Score & Frequency & $\begin{array}{c}\text { Percentage } \\
(\mathbf{\%})\end{array}$ & Category \\
\hline $\mathrm{x} \geq 16,25$ & 36 & 72,0 & Very good \\
\hline $13,75<$ to $<16,25$ & 14 & 28,0 & Good \\
\hline $11,25<$ to $<13,75$ & 0 & 0,0 & Sufficient \\
\hline $8,75<$ to $<11,25$ & 0 & 0,0 & Bad \\
\hline $\mathrm{x}<8,75$ & 0 & 0,0 & Very bad \\
\hline Total & 50 & 100,0 & \\
\hline
\end{tabular}

Based on the table above, it is known that $72 \%$ of the respondents stated that they were in the very good category, as much as $28 \%$ of the respondents stated that they were in the good category. It can be concluded that the empathy factor service quality is in the very good category.

\subsection{Discussion}

The observation results show that the management functions including planning, organizing, placing, directing and controlling have been carried out well by the Yogyakarta HSC Fitness Center. The planning function has been carried out with the existence of global, strategic and operational planning. Planning is carried out through meetings every month, and then breakdown in each unit to be ready to be implemented. The organizing function has been carried out by the HSC Fitness Center Yogyakarta by arranging work organization, determining human resources and monitoring responsibilities [37], [38], [39]. This show that HSC Fitness Center doing a positive organizational performance at all [32].

The organizational structure follows the management unit of the HSC management. All aspects of leadership and managerial have carried out the organizational function together. The placement function is carried out by the Yogyakarta HSC Fitness Center with human resources planning, employee withdrawals, employee training, employee appraisals and employee orientation. What has not been done is that there is no remuneration for employees. The placement function is carried out in each unit through consideration and adjusted to the conditions and needs of each unit. The function of directing has been carried out by the HSC Fitness Center Yogyakarta, indicated by the presence of leading, motivating and communicating. The directing function is performed in each unit. Each management implements a function of direction to subordinates.

The control function has been carried out by the HSC Fitness Center Yogyakarta, indicated by the presence of personal controls, action controls and result controls. Overall, the management function has been carried out by the Yogyakarta HSC Fitness Center which can support to provide optimal service quality. The things mentioned above have a good impact in improving the management quality of the HSC Fitness Center. HSC Fitness Center is a medium fitness center that has a positive effect with the implementation of good management functions [40].

Based on table 2, it is known that the percentage value of the total score of the direct evidence factor is $80.65 \%$. The service quality of direct evidence is measured in several indicators and outlined in the questionnaire questions. The results of the score analysis for each question item are as follows.

The percentage value of the total score of the direct evidence factor is $80.65 \%$. These results indicate that seen from each item of the question the quality of service, the direct evidence factor has been done very well by the Yogyakarta HSC Fitness Center. The highest score percentage is in the cleanliness statement of the maintained training room with a percentage of $90 \%$. These results indicate that the cleanliness of the practice room is well maintained. Yogyakarta HSC Fitness Center staff always maintain the cleanliness of the exercise room by regularly cleaning the exercise room before opening or before closing. The lowest score percentage on the waiting room statement is quite adequate with a percentage value of $65 \%$. When many members are doing the exercises at the same time, the waiting area is limited. This condition makes member ratings low.

Based on table 3 , it is known that the percentage value of the total score of the reliability factor is $80.2 \%$. The service quality reliability factor is measured in several indicators and outlined in the questionnaire questions. The percentage value of the total score of the reliability factor is $80.2 \%$. These results indicate that seen from each item the service quality reliability factor has been carried out well by the Yogyakarta HSC Fitness Center. The highest score percentage is in the statement of the HSC Fitness Center opening time with a percentage of $87.5 \%$. These results indicate that the opening times at the HSC Fitness Center are right on schedule. Yogyakarta HSC Fitness Center officers are always on time to open the HSC Fitness Center. The lowest score percentage on statements in member training is always assisted by the instructor with a percentage value of $71 \%$. When many members do the exercises at the same time, the instructor's attention is diverted among many members, so the instructor cannot always help one member but must pay attention to all members. This condition makes member ratings low.

Based on table 4, it is known that the percentage value of the total score of the responsiveness factor is $84.4 \%$. The service quality of the responsiveness factor is measured in several indicators and outlined in the questionnaire questions. These results indicate that seen from each item of the question, the service quality of the responsiveness factor has been carried out very well by the Yogyakarta HSC Fitness Center. The highest score percentage is in the statement that the instructor is always friendly in serving members with a percentage of $89 \%$. These results indicate that the instructor's friendliness in providing services is felt by the members. Instructor 
friendliness is one form of the forefront of the responsiveness factor that supports the realization of service quality at the HSC Fitness Center. The lowest score percentage on the HSC Fitness Center statement responds to criticism and input from members with a percentage value of $80.5 \%$. The lowest percentage value of answers in the aspect of responsiveness still shows a high percentage, meaning that the HSC Fitness Center has responded to criticism and input from members very well, so that service responsiveness can be realized.

Based on table 5 , it is known that the percentage value of the total score of the guarantee factor is $83.1 \%$. Quality of service assurance factor is measured in several indicators and outlined in the questionnaire questions. The results of the score analysis for each question item are as follows.

Based on table 5, it is known that the percentage value of the total score of the guarantee factor is $83.1 \%$. These results indicate that seen from each item of the question the quality of service, the guarantee factor has been done very well by the Yogyakarta HSC Fitness Center. The highest score percentage is in the statement that the HSC Fitness Center has instructors who have knowledge of sports fitness / the world of fitness with a percentage of $88 \%$. These results indicate that the instructor's knowledge about the sport of fitness / the world of fitness is very adequate so that it supports them in carrying out their duties as an instructor. The lowest score percentage in the HSC Fitness Center statement guarantees the member's vehicle is in the parking lot with a percentage value of $76.5 \%$. The lowest percentage value of answers in the aspect of guarantee still shows a high percentage, meaning that the safety of the members' vehicles is guaranteed at the HSC Fitness Center. In addition to adequate parking spaces, there are also officers who guard the parking lot for vehicles so that security is maintained.

Based on table 6, it is known that the percentage value of the total score for the empathy factor is $88.2 \%$. The service quality of the empathy factor is measured in several indicators and outlined in the questionnaire. The results of the score analysis for each question item are as follows. These results indicate that seen from each item the service quality factor of empathy has been done very well by the Yogyakarta HSC Fitness Center. The highest score percentage is in the statement of registration requirements at the HSC Fitness Center, which is very easy with a percentage of $92.5 \%$. These results indicate that to become a member at the HSC Fitness Center does not require difficult conditions. New members can easily join the HSC Fitness Center. The lowest score percentage in the HSC Fitness Center statement always anticipates the needs of members with a percentage value of $81.5 \%$. The lowest percentage value of answers on the aspect of empathy still shows a high percentage, meaning that the HSC Fitness Center always carries out its duties in meeting the needs of members. This has been felt directly by the members so that the service quality of the empathy factor can be manifested at the HSC Fitness Center.

With these things, HSC Fitness Center has a service quality that is worth to its customers. Various management functions in the application can meet the needs of members and increase member confidence in the HSC Fitness Center. This is a positive thing that the service quality of HSC Fitness Center is getting better with the support of planning, organizing, placement, leading and controlling carried out by the management of HSC Fitness Center [41]-[44].

\section{Conclusion}

Based on the results of research and discussion, it can be concluded that overall HSC Fitness Center Yogyakarta has implemented management functions in the form of planning, organizing, placing, directing, and controlling optimally, thus having a positive impact on service quality which includes several factors: direct evidence tangibles of $80.65 \%$, reliability of $80.2 \%$, responsiveness of $84.4 \%$, assurance of $83.1 \%$, and empathy of $88.2 \%$. The final conclusion of this study is that the implementation of the management function in HSC Fitness Center Yogyakarta have positive impact on service quality.

\section{REFERENCES}

[1] Y. Prasetyo and A. Nasrulloh, "Weight training with pyramid systems to increase the leg and back muscular strength, grip strength, pull, and push strength," Man India, vol. 97 , no. 24, 2017.

[2] A. Nasrulloh and I. S. Wicaksono, "Latihan bodyweight dengan total-body resistance exercise (TRX) dapat meningkatkan kekuatan otot," J. Keolahragaan, vol. 8, no. 1, 2020, doi: $10.21831 /$ jk.v8i1.31208.

[3] A. Nasrulloh et al., "Tricet Method to Increase the Hypertrophy Muscle," in Journal of Physics: Conference Series, 2020, vol. 1529, no. 3, doi: 10.1088/1742-6596/1529/3/032006.

[4] S. Nugroho, A. Nasrulloh, T. H. Karyono, R. Dwihandaka, and K. W. Pratama, "Effect of intensity and interval levels of trapping circuit training on the physical condition of badminton players," J. Phys. Educ. Sport, vol. 21, 2021, doi: 10.7752/jpes.2021.s3252.

[5] N. A. M. Mokmin, "The effectiveness of a personalized virtual fitness trainer in teaching physical education by applying the artificial intelligent algorithm," Int. J. Hum. Mov. Sport. Sci., Vol. 8, No. 5, pp. 258 - 264, 2020, DOI: 10.13189/saj.2020.080514.

[6] M. S. Antoni, G. Guntur, R. Festiawan, A. I. Nugraha, and F. I. Nurhadi, "Rockport walking fitness test apps: application of cardiorespiration fitness test with rockport method android based," MEDIKORA, vol. 20, no. 1, 2021, doi: 
10.21831/medikora.v20i1.34960.

[7] S. Suharjana, "ANALISIS PROGRAM KEBUGARAN JASMANI PADA PUSAT-PUSAT KEBUGARAN JASMANI DI YOGYAKARTA," MEDIKORA, 2015, doi: 10.21831/medikora.v11i2.2813.

[8] Harsuki, "Pengantar Manajemen Olahraga," Pt. Raja Grafindo Persada. 2013.

[9] Harsono, Manajemen Pengantar. Yogyakarta: STIE YKPN, 2010.

[10] A. Lis and M. Tomanek, "Sport management: Thematic mapping of the research field," J. Phys. Educ. Sport, 2020, doi: 10.7752/jpes.2020.s2167.

[11] M. A. Odio, "The Role of Time in Building Sport Management Theory," J. Glob. Sport Manag., 2021, doi: 10.1080/24704067.2018.1554979.

[12] J. Ndayisenga and Tomoliyus, "Effect of service quality and rates on satisfaction and loyalty of customer behavior at fitness," Int. J. Hum. Mov. Sport. Sci., Vol. 7, No. 2, pp. 25 32, 2019, DOI: 10.13189/saj.2019.070202

[13] W. S. Suherman, Modul Kuliah Manajemen Olahraga Pengantar Organisasi. Yogyakarta: FIK UNY, 2011.

[14] J. B. Parks, B. R. K. Zanger, and J. Quarterman, "Contemporary sport management," J. Sport Manag., 2001, doi: 10.1123/jsm.15.2.160.

[15] M. Manullang, "Manajemen Sumber Daya Manusia," J. Ekon., 2016.

[16] E. Eksteen, Sport Management Manual for Sport Management. 2019.

[17] E. Eksteen, D. D. J. Malan, and R. Lotriet, "Management competencies of sport club managers in the North- West Province, South Africa.," African J. Phys. Heal. Educ. Recreat. Danc., 2013.

[18] Yudha Febrianta, "Manajemen-Olahraga-Abad-21.Pdf," Prosiding Seminar Nasional "Optimalisasi Peran Pendidikan dalam Membangun Karakter Anak untuk Menyongsong Generasi Emas Indonesia. 2014.

[19] S. Bakhtiar, "Manajemen Olahraga," J. Chem. Inf. Model., 2015.

[20] B. Endeshaw, "Healthcare service quality-measurement models: a review," Journal of Health Research. 2020, doi: 10.1108/JHR-07-2019-0152.

[21] A. Afthanorhan, Z. Awang, N. Rashid, H. Foziah, and P. L. Ghazali, "Assessing the effects of service quality on customer satisfaction," Manag. Sci. Lett., 2019, doi: 10.5267/j.msl.2018.11.004.

[22] M. N. Nasution, "Manajemen Jasa Terpadu." Ghalia Indonesia, Bogor, p. 184, 2004.

[23] T. Fandi, Prinsip-prinsip Total Quality Service. 2004.

[24] R. Upadhyai, A. K. Jain, H. Roy, and V. Pant, “A Review of Healthcare Service Quality Dimensions and their Measurement," J. Health Manag., 2019, doi: 10.1177/0972063418822583.

[25] R. Islam, S. Ahmed, and K. M. Tarique, "Prioritisation of service quality dimensions for healthcare sector," Int. J. Med. Eng. Inform., 2016, doi: 10.1504/IJMEI.2016.075751.

[26] G. Medberg and C. Grönroos, "Value-in-use and service quality: do customers see a difference?," J. Serv. Theory Pract., 2020, doi: 10.1108/JSTP-09-2019-0207.

[27] V. D. Trinh and H. M. Nguyen, "Model of Relationships Among Marketing Public Relations, Service Quality and Attitude Toward Brand," ASEAN Mark. J., 2019.

[28] D. K. Nur' Najmah, P. G. Haji Menudin, and N. M. Laidey, "Factors affecting customer' perception toward service quality of grab," Int. J. Recent Technol. Eng., 2019.

[29] A. S. A. Shurair and S. Pokharel, "Stakeholder's perception of service quality: a case in Qatar," Qual. Assur. Educ., 2019, doi: 10.1108/QAE-05-2017-0023.

[30] C. Z. Yong, Y. W. Yun, and L. Loh, "The Quest for Global Quality,” Pustaka Delapratasa, Jakarta., 2003.

[31] S. M. Yildiz, "Instruments for measuring service quality in sport and physical activity services," Collegium Antropologicum, vol. 36, no. 2. 2012.

[32] J. García Fernández, J. Fernández Gavira, E. Pereira, and J. Carvalho, "Human resources management in fitness centers and their relationship with the organizational performance," Intang. Cap., vol. 10, no. 5, 2014, doi: 10.3926/ic.537.

[33] J. León-Quismondo, J. García-Unanue, and P. Burillo, "Best practices for fitness center business sustainability: A qualitative vision," Sustain., vol. 12, no. 12, 2020, doi: $10.3390 / \mathrm{su} 12125067$.

[34] F. Tjiptono, Prinsip-prinsip Total Quality Service, 5th ed. Yogyakarta: Andi Ofset, 2005.

[35] D. Marcel, Service Quality in Concept and Theory. USA: American Press, 2003.

[36] E. Tsitskari, D. Tsiotras, and G. Tsiotras, "Measuring service quality in sport services," Total Quality Management and Business Excellence, vol. 17, no. 5. 2006, doi: 10.1080/14783360600588190.

[37] C. Nite and J. Nauright, "Examining institutional work that perpetuates abuse in sport organizations," Sport Manag. Rev., 2020, doi: 10.1016/j.smr.2019.06.002.

[38] Q. ZENG and L. HU, "A Study on Strategic Human Resource Management and Sports Organization Performance," DEStech Trans. Econ. Bus. Manag., 2017, doi: 10.12783/dtem/icem2017/13170.

[39] M. Winand, "Managing high performance sport," Eur. Sport Manag. Q., 2014, doi: 10.1080/16184742.2014.9249 78.

[40] A. Koustelios, "Identifying important management competencies in fitness centres in greece," Manag. Leis., vol. 8, no. 3, 2003, doi: 10.1080/1360671032000123672.

[41] A. Suarjaya and P. G. D. Herlambang, "PENGARUH PELAKSANAAN MAINTENANCE DAN LINGKUNGAN FISIK TERHADAP KEPUASAN PENGGUNA JASA GHADA GYM DAN FITNESS CENTER DI DENPASAR," J. Manaj. dan Bisnis Equilib., vol. 6 , no. 1, 2020, doi: 10.47329/jurnal mbe.v6i1.425. 
[42] S. Y. Lee, "Service quality of sports centers and customer loyalty," Asia Pacific J. Mark. Logist., vol. 29, no. 4, 2017, doi: 10.1108/APJML-10-2016-0191.

[43] J. García-Fernández, P. Gálvez-Ruíz, J. Fernández-Gavira, L. Vélez-Colón, B. Pitts, and A. Bernal-García, "The effects of service convenience and perceived quality on perceived value, satisfaction and loyalty in low-cost fitness centers,"
Sport Manag. Rev., vol. 21, no. 3, 2018, doi: 10.1016/j.smr.2017.07.003.

[44] J. García-Fernández, P. Gálvez-Ruíz, B. G. Pitts, L. Vélez-Colón, and A. Bernal-García, "Consumer behaviour and sport services: an examination of fitness centre loyalty," Int. J. Sport Manag. Mark., vol. 18, no. 1-2, 2018, doi: 10.1504/IJSMM.2018.091342. 